\title{
KAJIAN KEBERHASILAN PERTUMBUHAN TANAMAN NYAWAI (Ficus variegata Blume) DI KHDTK CIKAMPEK, JAWA BARAT
}

\author{
(Study of growth success of nyawai (Ficus variegata Blume) \\ plantation at KHDTK Cikampek, West Java) \\ Riskan Effendi \\ ${ }^{1}$ Pusat Penelitian dan Pengembangan Peningkatan Produktivitas Hutan \\ Jalan Gunung Batu 5. Kotak Pos 165. Tel. 0251-8631238; Fax. 0251-7520005 Bogor \\ e-mail : riskan51@yahoo.co.id
}

Naskah masuk : 10 Februari 2012; Naskah diterima : 11 Maret 2012

\begin{abstract}
Plantation forests will be the main source of raw materials for forest industries and to fulfill timber needs of local community. One of promising alternative tree species to be developed for plantation forest is nyawai (Ficus variegata Blume). Study of nyawai plantation establishment was carried out at KHDTK (Forest Area with Special Purpose) of Cikampek, West Java end of 2009. Nyawai plantation was combined with intercropping (agroforestry system) namely cucumbers and long beans. Fertilizer provided on cucumber plants consisted of organic fertilizer (sheep dung manure) and inorganic fertilizers. The amount of urea, Phonska, TSP and Za were as much as $700 \mathrm{~kg}$ for an area of $0.25 \mathrm{ha}$ and sheep /goat manure as much as 3 tons for 0.25 ha area for cucumber planting. At the time of planting long beans as much as $300 \mathrm{~kg}$ of NPK fertilizer and sheep/goat manure as much as 1 ton were given to $0.25 \mathrm{ha}$. Spacing of nyawai tree is $6 \mathrm{~m} \times 3 \mathrm{~m}$ with the number of trees as many as 120 trees with an area of $0.25 \mathrm{ha}$. Based on results of measurement, the survival of two years old nyawai plantation was high namely $95.0 \%$ on average. Average diameter was $7.22 \mathrm{~cm}$, average tree height $6.90 \mathrm{~m}$ and average canopy area was $12.90 \mathrm{~m}^{2}$. The average diameter increment of nyawai at twoyears age was $3.61 \mathrm{~cm}$ per year and the height increment was 3.45 m per year. In addition to its fast-growing species nyawai tree has a good ability to coppice and this species also began to fruit at two years age.
\end{abstract}

Keywords: Ficus variegata Blume, canopy area, survival, diameter growth, height growth

\begin{abstract}
ABSTRAK
Hutan tanaman menjadi sumber bahan baku utama untuk industri perkayuan dan untuk memenuhi kebutuhan kayu masyarakat. Salah satu jenis pohon alternatif untuk dikembangkan adalah nyawai (Ficus variegata Blume). Kajian penanaman nyawai telah dilakukan di KHDTK Cikampek akhir tahun 2009. Penanaman nyawai dikombinasikan dengan tumpangsari (agroforestry) mentimun dan kacang panjang. Pupuk yang diberikan pada tanaman mentimun adalah pupuk kandang kotoran domba dan pupuk anorganik. Banyaknya pupuk Urea, Phonska,TSP dan Za sebanyak $700 \mathrm{~kg}$ untuk seluas 0,25 ha dan pupuk kotoran domba sebanyak tiga ton untuk luasan 0,25 ha. Pada waktu penanaman kacang panjang diberi pupuk NPK sebanyak $300 \mathrm{~kg}$ dan pupuk kandang kotoran domba sebanyak satu ton untuk 0,25 ha. Jarak tanam pohon nyawai adalah $6 \mathrm{~m} \times 3 \mathrm{~m}$ dengan jumlah tanaman sebanyak 120 pohon dengan luas $0,25 \mathrm{ha}$. Berdasarkan pengukuran diperoleh hasil persentase tumbuh nyawai umur dua tahun yang tinggi yaitu rata-rata $95 \%$, rata-rata diameter adalah $7,22 \mathrm{~cm}$, rata-rata tinggi $6,90 \mathrm{~m}$ dan rata-rata luas tajuk 12,90 $\mathrm{m} 2$. Ratarata riap diameter umur dua tahun adalah $3,61 \mathrm{~cm}$ per tahun dan rata-rata riap tinggi adalah 3,45 $\mathrm{m}$ per tahun. Selain jenis tumbuh cepat (fast growing species), pohon nyawai mempunyai kemampuan trubusan yang baik dimana pohon yang patah dapat tumbuh kembali dan jenis ini juga mulai berbuah pada umur dua tahun.
\end{abstract}

Kata kunci : Ficus variegata Blume, luas tajuk, persen tumbuh, pertumbuhan diameter, pertumbuhan tinggi 


\section{PENDAHULUAN}

Salah satu program Kementerian Kehutanan yang saat ini sedang didorong adalah pembangunan hutan tanaman baik dalam bentuk hutan tanaman industri (HTI) maupun hutan tanaman rakyat (HTR) dan memfasilitasi hutan rakyat (HR). Pada Jumpa Pers akhir tahun 2011, salah satu kegiatan yang akan dilaksanakan oleh Menteri Kehutanan pada Tahun 2012 adalah menambah/mencadangkan hutan tanaman indsustri (HTI) dan hutan tanaman rakyat (HTR) seluas 500.000 ha (Kementerian Kehutanan 2011).

Jenis-jenis pohon yang ditanam umumnya jenis tumbuh cepat (fast growing species) yang sudah dikenal seperti mangium (Acacia mangium), krasikarpa (A. crasicarpa), eukaliptus (Eucalyptus pellita, E.urograndis), jabon (Anthocephalus cadamba), sengon (Falcataria moluccana). Salah satu jenis alternatif yang cukup menjanjikan untuk dikembangkan sebagai jenis hutan tanaman adalah nyawai.

Jenis pohon nyawai (Ficus variegata Blume) suku Moraceae tumbuh secara alami di hutan bekas terbakar hebat pada tahun 1998 yang terjadi di Kalimantan Timur. Nama lain nyawai adalah kundang, gondang (Jawa, Bali); kondang (Sunda), ara, arah, aro, barai silai uding, haru kucing (Sumatera); hara, lua, nyawi, nyawai (Kalimantan), aga, andarahi montaha, bunta, rolli (Sulawesi); akau, andei yeva, gondal, sesem, kabato (Maluku) ; ganalang, kanjilu (Sumba) (Sumarni et al., 2009). Jenis pionir ini ditemukan bersama jenis-jenis pionir lainnya yaitu makaranga (Macaranga sp.), jabon (Anthocephalus cadamba), benuang (Octomeles sumatrana), dan nuklea (Nuclea $\mathrm{sp}$ ). Tinggi batang bebas cabang 10-15 m dengan diameter $50-60 \mathrm{~cm}$. (PT ITCIKU 2008).

Pengadaan bibit nyawai dapat dilakukan melalui biji dan setek pucuk. Persen jadi biji yang segar mencapai 80 - $85 \%$. Dalam satu pohon biasanya terdapat buah muda, buah tua dan buah masak. Buah nyawai menempel pada batang. Biji nyawai sangat kecil yang menempel pada daging buah, dalam $1 \mathrm{~kg}$ terdapat kurang lebih 3.000 .000 biji. Biji nyawai tidak bisa disimpan lama atau semi recalcitrant yaitu hanya sekitar enam bulan. Bibit yang berasal dari biji, siap untuk ditanam setelah mencapai tinggi $30-35 \mathrm{~cm}$ dan biasanya telah berumur $3-3,5$ bulan. Persen tumbuh bibit dari setek pucuk (stem cuttings) melalui penggunaan bahan setek dari kebun pangkasan (hedge orchard), mencapai $65-70 \%$. Bibit siap tanam dari setek pucuk dengan tinggi
$30 \mathrm{~cm}$ memerlukan waktu sekitar 3,5 - 4 bulan. Hutan tanaman nyawai seluas 508,02 ha telah ditanam di areal IUPHHK PT ITCIKU, Kalimantan Timur. Nyawai ditanam bersamasama dengan jenis meranti merah. (PT ITCIKU 2008 ; Hendromono dan Komsatun 2008).

Kayu nyawai dapat digunakan untuk kayu pertukangan dan pembuatan kayu lapis (plywood), bahkan digunakan untuk face veneer karena memiliki corak kayu yang baik, dimana kayunya berwarna cerah, yaitu kuning keputihan. Pembuatan vinir nyawai tanpa perlakuan diperoleh hasil yang baik dengan sudut kupas $91^{\circ} 30^{\prime}$ untuk tebal vinir $1,5 \mathrm{~mm}$. Berat jenis kayu nyawai $0,27(0,20-0,43)$, kelas kuat: V, kelas awet V-III. Jenis ini digolongkan dalam kelas keterawetan I yaitu mudah dilakukan pengawe-tan memiliki nilai kalor $4.225 \mathrm{cal} / \mathrm{gram}$ (Sumarni et al., 2009 ; PT ITCIKU 2008). Menurut Hendromono dan Komsatun (2008) dan Effendi (2009) berdasarkan hasil penelitian dan pengamatan mereka jenis nyawai dapat di rekomendasikan untuk pembangunan hutan tanaman.

Tujuan dari penelitian ini adalah untuk mengetahui keberhasilan pertumbuhan jenis pohon nyawai ( $F$. vriegata) di KHDTK Cikampek, Jawa Barat.

\section{METODE PENELITIAN}

\section{A. Lokasi Penelitian}

Lokasi penelitian tanaman nyawai terletak di Kawasan Hutan dengan Tujuan Khusus (KHDTK) Hutan Penelitian Cikampek yaitu pada Petak 24. Menurut administrasi pemerintahan desa, hutan penelitian ini termasuk desa Kamojing, kecamatan Cikampek, Kabupaten Karawang, provinsi Jawa Barat. Hutan penelitian ini terletak di sebelah selatan Kota Cikampek. KHDTK Cikampek dibangun pada tahun 1937 dengan luas 51,1 ha dan pengelolaannya berada dibawah Pusat Litbang Peningkatan Produktivitas Hutan Bogor. Secara geografis terletak antara $06^{\circ} 25^{\prime} 00^{\prime \prime}-06^{\circ} 25^{\prime} 48^{\prime \prime}$ Lintang Selatan dan antara $107^{\circ} 27^{\prime} 36^{\prime \prime}-107^{\circ} 27^{\prime} 50$ " Bujur Timur dengan ketinggian $50 \mathrm{~m}$ dpl. Topografi datar sampai bergelombang ringan dengan lereng $<9 \%$. Curah hujan rata-rata tahunan 1.796 $\mathrm{mm}$, suhu $21^{\circ}-32^{\circ} \mathrm{C}$ dan kelembaban $70-84 \%$. Jenis tanah sebagian besar Latosol merah berkonkresi, Laterit air tanah dan Latosol merah kekuningan dan kondisi tanah masam ( $\mathrm{pH} 4,9$ 5,2). Sampai dengan tahun 2011 sebanyak 
63 jenis pohon telah ditanam di hutan penelitian ini (Anonim, 2010).

\section{B. Bahan Penelitian}

Bahan penelitian yang digunakan adalah hutan tanaman nyawai yang ditanam pada bulan Desember 2009 dengan sumber benih berasal dari Kalimantan Timur. Luas petak 0,25 ha. Penanaman tanaman tumpangsari dengan mentimun dan tanaman kacang panjang dilakukan pada tahun 2010. Pupuk yang diberikan pada tanaman mentimun adalah pupuk kandang kotoran domba dan pupuk anorganik. Banyaknya pupuk Urea, Phonska,TSP dan Za sebanyak $700 \mathrm{~kg}$ untuk seluas 0,25 ha. Pupuk urea mengandung usur $\mathrm{N}$ dengan kadar $46 \%$, phonska mengandung unsur-unsur $\mathrm{N} ; 15 \%, \mathrm{P}: 15 \%$, $\mathrm{K}: 15 \%$ dan $\mathrm{S}: 10 \%$, pupuk TSP mengandung $\mathrm{P}$ sebesar 44 - $46 \%$ dan Za terdiri dari unsur $\mathrm{N}: 21 \%$ dan S : $24 \%$. Pupuk kandang dari kotoran domba sebanyak tiga ton untuk luasan 0,25 ha. Penanaman kacang panjang dilakukan dengan pemberian pupuk NPK (N: $15 \%$, P: $15 \%$ dan $\mathrm{K}: 15 \%$ ) sebanyak $300 \mathrm{~kg}$ dan pupuk kandang kotoran domba sebanyak satu ton untuk 0,25 ha.

\section{Metode Penelitian}

Metode penelitian berupa penanaman nyawai dalam jalur, sebanyak 10 jalur tanam dengan panjang $40 \mathrm{~m}$ yng merupakan ulangan, telah dibuat dengan jarak antar jalur enam $\mathrm{m}$. Jarak tanam pohon dalam jalur adalah tiga $\mathrm{m}$, dengan demikian jarak tanam $6 \mathrm{~m} \mathrm{x} 3 \mathrm{~m}$. Pada saat penanaman jumlah yang ditanam sebanyak
120 bibit. Penanaman nyawai dilakukan pada bulan Desember 2009. Bibit tanaman berasal dari Kalimantan Timur. Pengukuran ulang dilakukan pada bulan Desember 2011 atau pada umur dua tahun. Dalam kajian ini digunakan pendekatan kuantitatf.

Respon yang diamati kajian adalah persentase tumbuh tanaman umur dua tahun (survival), pertumbuhan diameter, pertumbuhan tinggi dan luas tajuk masing-masing pohon.

\section{Analisa Data}

Data hasil pengukuran berupa persen tumbuh setiap jalur, pengukuran diameter setinggi dada (dbh), tinggi pohon total dan luas tajuk dilakukan tabulasi. Pengolahan data selanjutnya berupa rata-rata persen tumbuh, rata-rata diameter, rata-rata tinggi pohon dan rata-rata luas tajuk, serta dilakukan penghitungan tiap penyebaran pohon menurut diameter dan tinggi yang disajikan dalam grafik serta sebaran hubungan luas tajuk dengan diameter batang.

\section{HASIL DAN PEMBAHASAN}

\section{A. Hasil}

Pengukuran yang dilakukan terhadap tanaman nyawai umur dua tahun di KHDTK Cikampek, Jawa Barat meliputi persen tumbuh (survival), rerata diameter setinggi dada $(1,3 \mathrm{~m})$, rerata tinggi pohon dan rerata luas tajuk. Secara ringkas hasil-hasil pengukuran tersebut disajikan disajikan pada Tabel 1.

Tabel(Table) 1. Persen tumbuh, rerata diameter, rerata tinggi dan rerata luas tajuk tanaman nyawai umur dua tahun di Cikampek (Survival, mean of diameter, mean of height and mean of canopy area of nyawai plantation two years old at Cikampek)

\begin{tabular}{|c|c|c|c|c|}
\hline $\begin{array}{c}\text { No. Jalur } \\
\text { (Stripe no.) }\end{array}$ & $\begin{array}{c}\text { Persen Tumbuh } \\
\text { (Survival) }(\%)\end{array}$ & $\begin{array}{c}\text { Rerata Diameter } \\
\text { (Mean of Diameter } \\
(\mathrm{cm})\end{array}$ & $\begin{array}{c}\text { Rerata tinggi } \\
(\text { Mean of height }) \\
(\mathrm{m})\end{array}$ & $\begin{array}{c}\text { Rerata luas tajuk } \\
(\text { Mean of canopy area }) \\
\left(\mathrm{m}^{2)}\right.\end{array}$ \\
\hline 1 & 83,33 & 6,20 & 6,35 & 9,47 \\
2 & 100,00 & 6,84 & 6,67 & 12,57 \\
3 & 100,00 & 6,52 & 6,58 & 12,95 \\
4 & 91,67 & 6,22 & 6,22 & 13,38 \\
5 & 100,00 & 7,11 & 7,00 & 12,31 \\
6 & 100,00 & 7,68 & 7,21 & 14,38 \\
7 & 91,67 & 8,32 & 7,76 & 15,07 \\
8 & 91,67 & 8,36 & 7,18 & 11,65 \\
9 & 100,00 & 7,53 & 7,09 & 13,03 \\
10 & 91,67 & 7,47 & 6,95 & 14,21 \\
\hline
\end{tabular}


Selanjutnya untuk mengetahui penyebaran pohon berdasarkan diameternya disajikan pada Gambar 1.

Informasi penyebaran jumlah pohon menurut tingginya disajikan pada Gambar 2 .
Selain pengukuran juga dilakukan pengamatan terhadap tegakan. Diketahui bahwa jenis nyawai mampu bertunas kembali (coppice) bila patah. Hasil pengamatan individu pohon diperoleh informasi bahwa beberapa pohon nyawai mulai berbuah pada umur dua tahun.

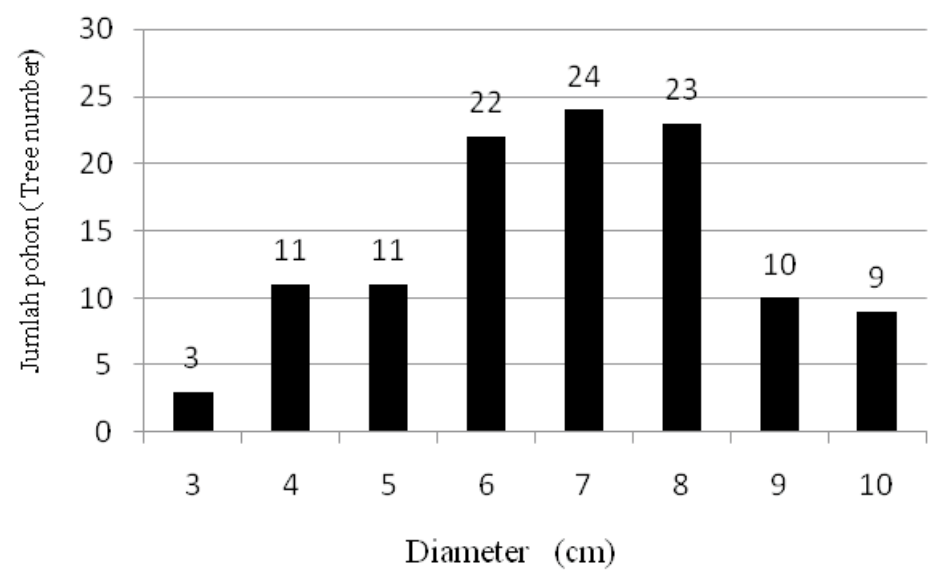

Gambar (Figure) 1. Penyebaran jumlah pohon menurut diameter (Distribution of tree number according to diameter)

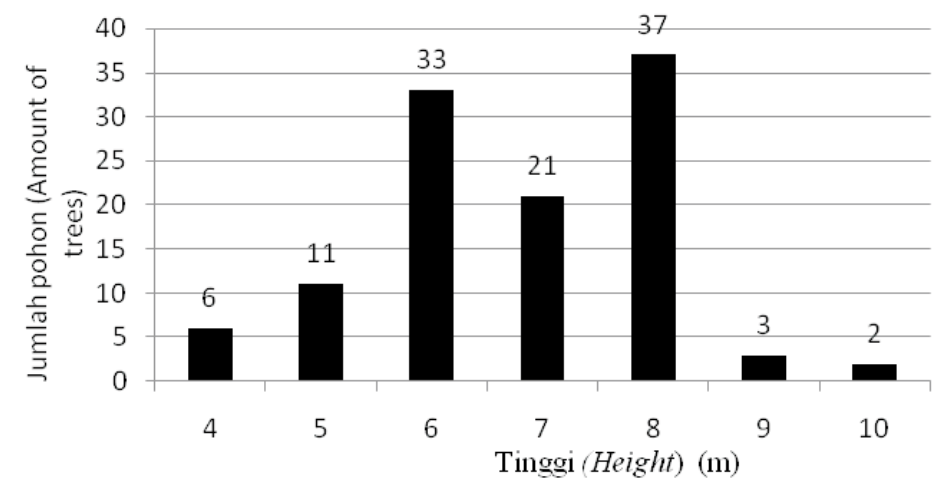

Gambar(Figure) 2. Penyebaran jumlah pohon menurut tinggi(Distributionof trees based on tree height)

\section{B. Pembahasan}

\section{Persentase tumbuh}

Persentase tumbuh (survival) tanaman nyawai di Cikampek sampai umur dua tahun cukup tinggi yaitu lebih dari $83 \%$ dan bahkan mencapai $100 \%$ pada lima jalur tanam. Adapun rata-rata persen tumbuhnya adalah 95,0\%. Data Tabel 1 menunjukkan bahwa jenis pohon nyawai menjanjikan untuk dijadikan sebagai salah satu jenis hutan tanaman dimana mempunyai persen tumbuh yang tinggi.

Evans (1986) menyatakan bahwa persentase tumbuh pada tanaman jarak rapat $(1250$ pohon/ha) bisa lebih rendah yaitu sekitar $80 \%$ (mortalitas $20 \%$ ), namun untuk tanaman jarak lebar, persen tumbuh yang dapat diterima paling tidak $90 \%$ (mortalitas 10\%). Menurut Pedoman Penilaian Tanaman Kegiatan Rehabilitasi Hutan dan Lahan Kalimantan Timur (Anonim 2003) persen tumbuh tanaman dibagi dalam (a) sangat berhasil (> $85 \%$ ) (b) berhasil (75\% - $85 \%)$, (c) cukup berhasil ( $65 \% \mathrm{~s} / \mathrm{d}<75 \%$ ), (d) kurang berhasil $(55 \%-65 \%)$ dan (e) gagal $(<55 \%)$. Pada tanaman jati bila persen tumbuh kurang dari $50 \%$ maka penanaman harus diulang kembali pada tahun berikutnya. Di KHDTK Cikampek diperoleh informasi rata-rata persentase tumbuh tanaman sengon umur empat bulan sebesar $86,83 \%(82,47 \%$ - 93,38\%) (Hadiyan 2010). Selanjutnya hasil penelitian Mindawati dan Heryati ( 2006) di KHDTK Haurbentes, 
Jasinga, Jawa Barat persen tumbuh tanaman Shorea stenoptera dan S. mecystopterix mencapai $68,89 \%$.

Hasil pengamatan pada tanaman nyawai di lapangan diketahui bahwa jenis nyawai mampu tumbuh kembali sebagai trubusan (coppice) bila patah atau terpotong. Hal ini merupakan keuntungan lainnya dari jenis nyawai.

\section{Pertumbuhan diameter}

Rata-rata diameter tanaman nyawai umur dua tahun di Cikampek (Tabel 1) adalah 7,22 cm yang berkisar antara $6,20 \mathrm{~cm}$ sampai $8,36 \mathrm{~cm}$. Bahkan berdasarkan individu pohon terdapat sembilan pohon $(7,5 \%)$ berdiameter diatas $10 \mathrm{~cm}$. Riap diameter sampai umur dua tahun adalah 3,6 cm - 4,18 cm per tahun bahkan dapat mencapai $5 \mathrm{~cm}$ per tahun.

Pertumbuhan tinggi dan diameter pohon sangat penting dalam pembangunan hutan tanaman. Sejalan dengan bertambahnya umur pohon maka pertumbuhan diameter akan bertambah sesuai dengan sifat genetiknya. Jenis pohon pionir umumnya tumbuh lebih cepat dibandingkan dengan jenis klimaks. Seiring dengan kemajuan teknologi maka untuk pembuatan kayu lapis sudah dapat dilakukan mulai dari diameter
$30 \mathrm{~cm}$ ke atas. Untuk jenis cepat tumbuh diameter $30 \mathrm{~cm}$ dapat dicapai pada umur sekitar $10-12,5$ tahun atau bahkan lebih cepat.

Menurut Evans (1986), hubungan pertumbuhan pohon dengan umur adalah pola sigmoid dimana pada umur muda tumbuh sedang lalu cepat sekali dan setelah tua pertumbuhannya kecil atau konstan. Daniel et al., (1987) dalam Riyanto dan Pamungkas, (2010) mengemukakan bahwa pertumbuhan suatu jenis pohon adalah fungsi dari umur tegakan, dimana sifatnya tergantung pada jenis dan kualitas tempat tumbuh.

Pohon nyawai yang berdiameter kurang dari $5 \mathrm{~cm}$ umumnya terletak di bagian pinggir (Gambar 3) yang berbatasan dengan tegakan tua yang tingginya sekitar $20 \mathrm{~m}$, dimana cahaya yang masuk lebih sedikit/terlindung. Pohon-pohon yang terletak dibagian tengah, dimana mendapat sinar matahari penuh, umumnya mempunyai diameter berkisar antara 6-10 $\mathrm{cm}$ (Gambar 3). Ini mengindikasikan bahwa nyawai dalam pertumbuhannya memerlukan cahaya penuh (full light demanders).

Pertumbuhan tanaman nyawai dibandingkan dengan jenis tumbuh cepat lainnya disajikan pada Tabel 2 .

Tabel(Table) 2. Tinggi dan diameter beberapa jenis tanaman menurut umur (Height and diameter of several tree species according to their age).

\begin{tabular}{|l|l|c|c|c|l|}
\hline No & \multicolumn{1}{|c|}{ Jenis (Species) } & $\begin{array}{c}\text { Umur (th) } \\
(\text { Age, yr })\end{array}$ & $\begin{array}{c}\text { Tinggi } \\
(\text { Height }) \\
(\mathrm{m})\end{array}$ & $\begin{array}{c}\text { Diameter } \\
(\text { Diameter }) \\
(\mathrm{cm})\end{array}$ & \multicolumn{1}{|c|}{$\begin{array}{c}\text { Pustaka } \\
\text { (References })\end{array}$} \\
\hline 1 & Acacia mangium & 2 & $9-12$ & $8-11$ & Hardiyanto et al., 2010 \\
\hline 2 & Eucalyptus urograndis & 2 & 13,34 & 9,91 & Mindawati, 2011 \\
\hline 3 & Eucalyptus pellita & 2 & 7,94 & 7,89 & Leksono dan Setyaji 2004 \\
\hline 4 & Falcataria moluccana & 2 & - & 5,03 & Riyanto et al., 2010 \\
\hline 5 & Falcataria moluccana & 2 & $2,4-11,0$ & $5,3-11,0$ & Suharlan et al.,1993 \\
\hline 6 & Ochroma lagopus & 2 & 8,8 & 13,2 & Suharlan et al.,1993 \\
\hline 7 & Anthpcephalus cadamba & 3 & $6,8-8,8$ & $7,6-9,9$ & Suharlan et al.,1993 \\
\hline 8 & Ficus variegata (Kaltim) & 2 & 2,04 & 1,6 & Effendi, 2010. \\
\hline 9 & Ficus variegata & $\mathbf{2}$ & $\mathbf{6 , 9 0}$ & $\mathbf{6 - 8}$ & Artikel karya tulis ilmiah ini \\
\hline
\end{tabular}

Bila dibandingkan dengan jenis yang sama di Kalimantan Timur (Tabel 2) maka nyawai di Cikampek jauh lebih cepat pertumbuhannya. Hal ini diduga karena tanaman nyawai di Kalimantan Timur tidak dikombinasikan dengan sistem agroforestry, dan pemeliharaannya tidak begitu intensif. Disamping itu nyawai di Kalimantan Timur diganggu oleh hama rusa yang suka sekali memakan daun nyawai yang muda, akibatnya banyak tanaman yang tumbuh tidak normal. Bila dibandingkan dengan jenis E.urograndis hybrid yang merupakan hasil persilangan antara E.urophylla dan E.grandis yang dikembangkan di PT Toba Pulp Lestari Sumatera Utara, dimana pertumbuhan diameter dan tingginya besar, maka pertumbuhan nyawai yang bukan hasil persi- 
langan berada dibawah E.urograndis. Jenis E.urograndis ini digunakan untuk produksi pulp dengan daur tebang 5-7 tahun (Mindawati et al., 2010).

Pertumbuhan diameter nyawai yang besar juga didukung oleh dampak tidak langsung dari pemupukan pada tanaman tumpangsari. Selain itu pada setiap tanaman diberi pupuk kandang kotoran kambing sebanyak $2 \mathrm{~kg}$ per tanaman. Pemeliharaan dengan cara memberi mulsa serasah disekitar tanaman berukuran $1 \mathrm{~m}$ x $1 \mathrm{~m}$ juga mempercepat pertumbuhan baik diameter maupun tinggi pohon nyawai. Siregar et al., (2008) mengemukakan hasil penelitian pada tegakan Acacia mangium di Sumatera Selatan dimana perlakuan serasah yang ditinggalkan di lapangan dibawah tegakan dan tersebar merata dapat meningkatkan diameter pohon. Hal yang sama juga dikemukakan oleh Hardiyanto dan Wicaksono (2008) dimana penyimpanan serasah (slash retention) di bawah tegakan meningkatkan pertumbuhan Acacia mangium di Sumatera Selatan.

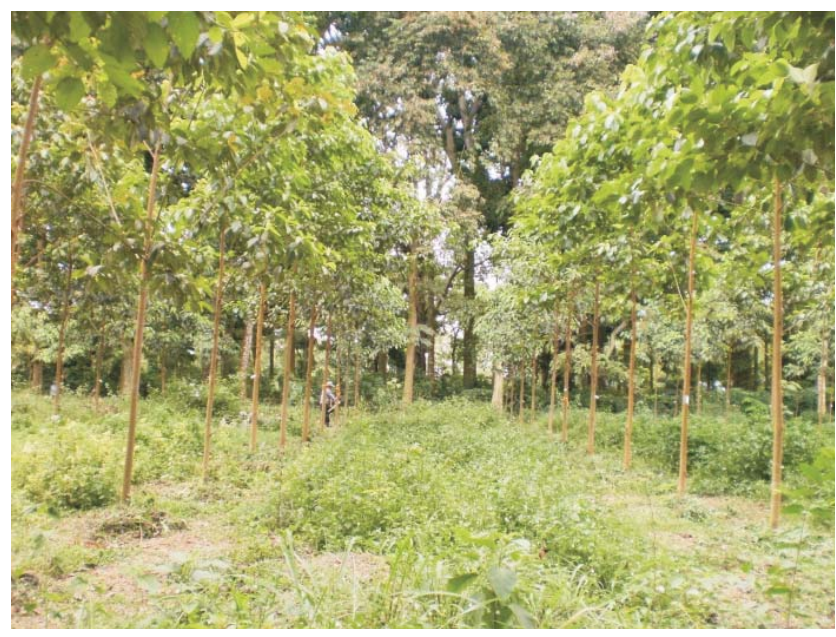

Gambar (Figure) 3. Tanaman nyawai umur 2 (dua) tahun di Cikampek, Jawa Barat (Two years old nyawai plantation at Cikampek, West Java)

\section{Pertumbuhan tinggi}

Berdasarkan hasil pengukuran tinggi seperti tertera pada Tabel 1, diperoleh informasi rata-rata tinggi tanaman nyawai umur dua tahun di Cikampek yaitu 6,90 m dengan kisaran antara $6,22 \mathrm{~m}$ sampai $7,76 \mathrm{~m}$, bahkan terdapat dua pohon mencapai tinggi $10 \mathrm{~m}$. Riap tinggi tanaman nyawai sampai umur dua tahun berkisar antara $3,113,88 \mathrm{~m}$ per tahun atau rata-rata $3,45 \mathrm{~m}$ tahun per tahun. Penyebaran jumlah pohon menurut tinggi yang disajikan pada Gambar 2, menunjukkan bahwa pohon nyawai dengan tinggi $6 \mathrm{~m}$ keatas mencapai $85 \%$.

Pertumbuhan tanaman menurut Vanclay (1994) adalah pertambahan dimensi pohon atau tegakan hutan selama periode waktu tertentu. Dikatakan lebih lanjut bahwa besaran pertumbuhan atau riap tegakan dapat diketahui dari parameter-parameter tinggi, diameter atau volume. Pertumbuhan tinggi pohon, baik tinggi bebas cabang maupun tinggi pohon, yang ditanam merupakan salah satu faktor penentu keberhasilan penanaman terutama untuk penghasil kayu pertukangan. Dengan tinggi bebas dahan yang proporsional maka pemanfaatan kayu dapat ditingkatkan. Hasil analisa tanah di KHDTK Cikampek (Rachman, 2012) menunjukkan bahwa pH 4,9 4,98 (masam), C : rendah-sedang $(1,71 \%-2,11 \%$, Bahan organik: sedang-tinggi $(2,95-3,64 \%), \mathrm{N}$ total sangat rendah $(0,08-0,10$ $\%)$, P sangat rendah (2,05-3,22 ppm) dan $\mathrm{K}$ sangat rendah $(0,11-0,12 \mathrm{me} / 100 \mathrm{~g})$. Adanya tumpangsari pada tanaman nyawai telah mampu mempercepat pertumbuhan nyawai. Input pupuk organik mencapai empat ton per 0,25 ha dan pemberian pupuk anorganik pada tanaman tumpangsari secara tidak langsung juga berpengaruh pada tanaman nyawai.

\section{Luas tajuk}

Luas tajuk tanaman nyawai umur dua tahun (Tabel 1) berkisar antara $9,47 \mathrm{~m}^{2}$ sampai $15,07 \mathrm{~m}^{2}$ dengan rata-rata $12,90 \mathrm{~m}^{2}$. Diameter tajuk rata-rata adalah $3,6 \mathrm{~m}^{2}$. Pada umur dua tahun tajuk nyawai relatif tidak terlalu besar. Dengan jarak tanam $6 \mathrm{~m} \times 3 \mathrm{~m}$, sebagian besar 
tajuk telah bersentuhan yaitu pada jarak antar pohon tiga $\mathrm{m}$, sedangkan antar jalur tanam enam m belum bersentuhan.

Hal ini menunjukkan bahwa pada jarak tiga m perlu dilakukan penjarangan. Tujuan penjarangan untuk memberikan ruangan bagi pertumbuhan nyawai selanjutnya supaya persaingan dalam mendapatkan cahaya dapat dikurangi.
Tajuk pohon mempunyai hubungan yang erat dengan pertumbuhan diameter dan tinggi. Pada Gambar 4 nampak bahwa terdapat korelasi yang linier antara luas tajuk dan diameter batang setinggi dada (1,3 m), dimana semakin luas tajuk pohon semakin besar diameter batang pada tanaman nyawai umur dua tahun di Cikampek, Jawa Barat.

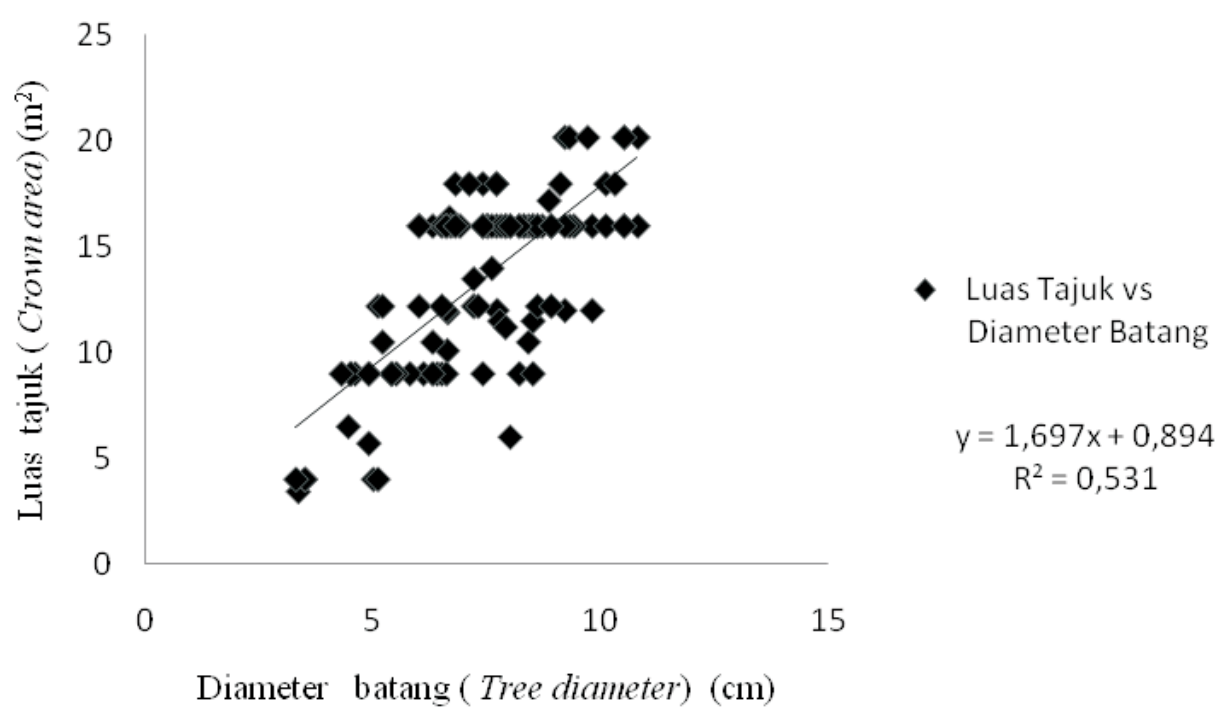

Gambar (Figure) 4. Hubungan antara luas tajuk $\left(\mathrm{m}^{2}\right)$ dan diameter pohon $(\mathrm{cm})$ nyawai umur dua tahun (Relationship between crown area $\left(\mathrm{m}^{2}\right)$ and tree diameter $(\mathrm{cm})$ of two years old nyawai)

Hasil pengamatan di lapangan diperoleh informasi bahwa tanaman nyawai umur dua tahun sudah mulai berbuah. Pada Gambar 5 tampak buah nyawai yang menempel di batang utama dan cabang pohon. Kemampuan berbuah dalam waktu yang relatif pendek ini memungkinkan untuk dilakukannya program pemuliaan pohon (tree breeding) untuk meningkatkan mutu genetik nyawai, dibandingkan dengan jenis pohon yang lama berbuahnya. Kegiatan pembangunan populasi dasar nyawai telah dilaksanakan oleh Balai Besar Penelitian Bioteknologi dan Pemuliaan Pohon Hutan Yogyakarta (Leksono, 2010).
Hal lain yang menguntungkan dari jenis pohon nyawai ini adalah kemampuan mengeluarkan terubusan (coppice) pada tanaman yang patah atau terpotong (Gambar 6). Keuntungan ini dapat dimanfaatkan untuk perbanyakan secara vegetatif yaitu pengadaan bibit dengan setek pucuk, seperti yang telah dipraktekkan di PT ITCIKU Kalimantan Timur. Selain itu juga dapat dimanfaatkan untuk perbanyakan tanaman melalui klon untuk pembangunan perhutanan klonal (clonal forest) guna peningkatan produktivitas tegakan. 


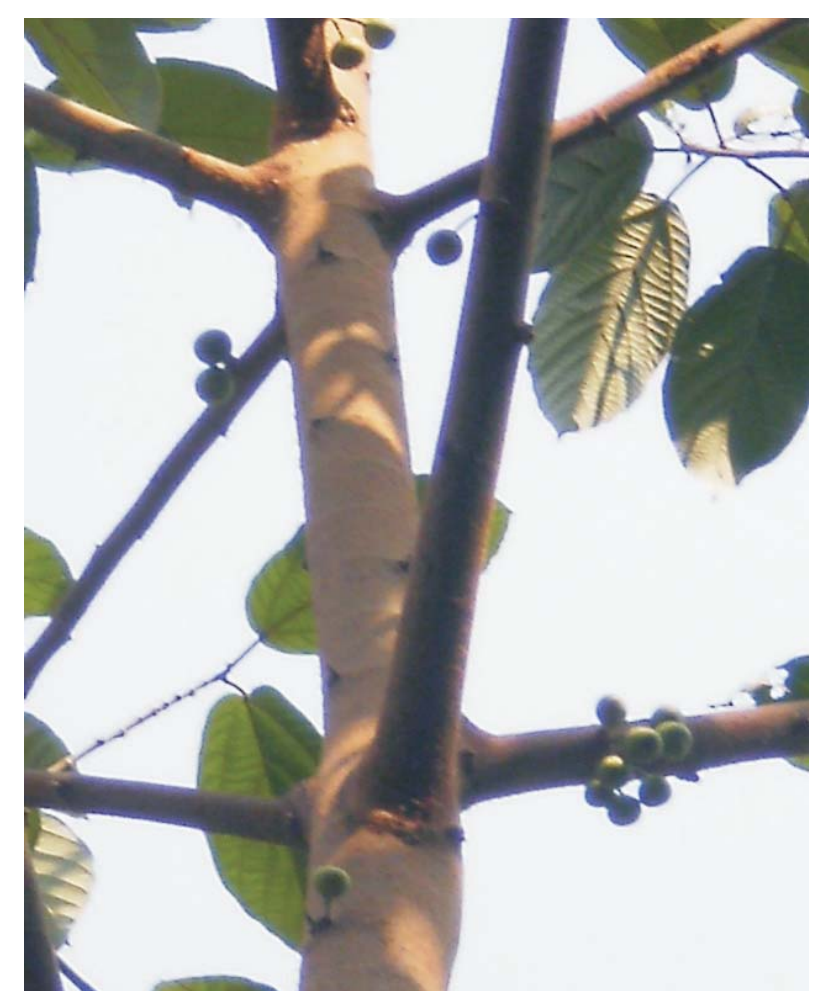

Gambar (Figure) 5. Pohon nyawai umur dua tahun yang telah berbuah (Two years old tree of nyawai with fruits)

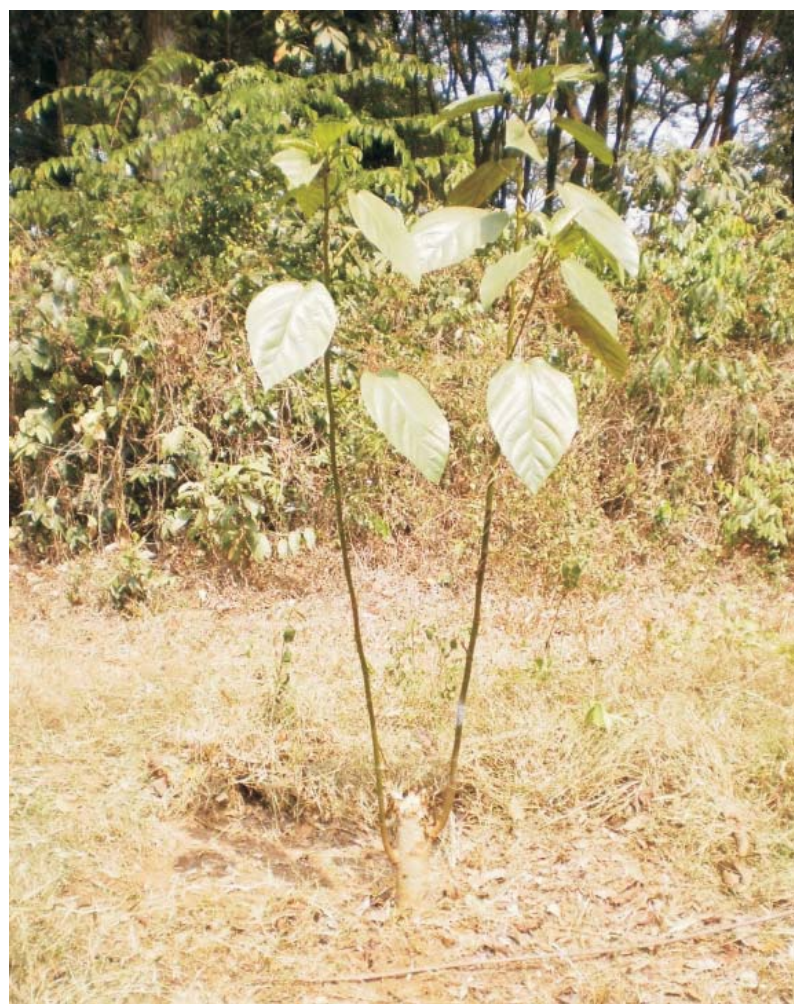

Gambar (Figure ) 6. Trubusan pada pohon nyawai (Coppice of nyawai tree) 


\section{KESIMPULAN DAN SARAN}

\section{A. Kesimpulan}

1. Persen tumbuh nyawai (Ficus variegata Blume) umur dua tahun (Desember 2009 Desember 2011) di KHDTK Cikampek, Jawa Barat, mencapai rata-rata $95,0 \%$, rata-rata diameternya $7,22 \mathrm{~cm}$, rata-rata tingginya $6,90 \mathrm{~m}$ dan rata-rata luas tajuknya $12,90 \mathrm{~m}^{2}$.

2. Riap diameter pohon nyawai sampai umur dua tahun adalah rata-rata $3,61 \mathrm{~cm}$ per tahun dan riap tinggi adalah rata-rata $3,45 \mathrm{~m}$ per tahun

3. Pohon nyawai mempunyai kemampuan trubusan (coppice) yang baik, disamping itu kelebihan dari jenis pohon nyawai adalah pohon sudah berbuah pada umur yang pendek (dua tahun).

\section{B. Saran}

Penelitian lanjutan diperlukan untuk mengetahui pertumbuhan sampai masak tebang dan teknik perbanyakan vegetatif lainnya seperti melalui klon.

\section{DAFTAR PUSTAKA}

Anonim. 2003. Pedoman Penilaian Tanaman Kegiatan Rehabilitasi Hutan dan Lahan Kalimantan Timur. Dinas Kehutanan Kalimantan Timur. Samarida.

Anonim. 2010. Mengenal KHDTK (Hutan Penelitian) Cikampek. Pusat Penelitian dan Pengembangan Peningkatan Produktivitas Hutan. Bogor.

Effendi, R. 2009. Prospek Penanaman Nyawai (FicusvariegataBlume) untuk HTI Kayu Pertukangan. Prosiding MAPEKI XI, Mapeki - Puslitbang Pemukiman Bandung.

Effendi, R. 2010. Pertumbuhan Awal Tinggi dan Diameter Tanaman Nyawai (Ficus variegata Blume) di Kalimantan Timur. Prosiding Workshop Sintesa Hasil Penelitian Hutan Tanaman. Pusat Penelitian dan Pengembangan Hutan Tanaman. Bogor.

Evans, J. 1986. Plantation Forestry in The Tropics. Clarendon Press Oxford, UK.

Hadiyan, Y. 2010 . Evaluasi Pertumbuhan Awal Kebun Benih Semai Uji Keturunan Sengon (Falcataria moluccana Sinonim Paraserianthes falcataria ) Umur 4 Bulan
Di Cikampek Jawa Barat. Jurnal Hutan Tanaman. Vol.7. No. 2. Pp.85-91. Pusat Penelitian dan Pengembangan Hutan Tanaman. Bogor.

Hardiyanto, E.B. and A. Wicaksono. 2008. Interrotation Site Management, Stand Growth and Soil Properties in Acacia mangium Plantations in South Sumatera, Indonesia.

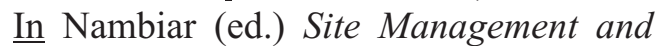
Productivity in Tropical Plantation Forests. 2008. Proceedings of Workshops in Piracicaba (Brazil) 22 - 26 November 2004 and Bogor (Indonesia) 6 - 9 November 2006. Center for International Forestry Research (CIFOR). Bogor.

Hardiyanto, E.B., D.Soepriyadi., A.Wicaksono., S.Untung dan M. Nurudin. 2010. Panduan Budidaya Pohon Acacia mangium. PT Musi Hutan Perhada. Palembang.

Hendromono. dan Komsatun. 2008. Nyawai (Ficus variegata Blume dan F. sycomoroides Miq) Jenis yang Berprospek Baik untuk Dikembangkan di Hutan Tanaman. Mitra Hutan Tanaman. Vol. 3 No. 3. Pusat Penelitian dan Pengembangan Hutan Tanaman. Bogor.

Kementerian Kehutanan. 2011. Executive Summary Jumpa Pers Menteri Kehutanan Akhir Tahun 2011. Kementerian Kehutanan Jakarta. Diakses tanggal 10 Januari 2012. Dephut.go.id

Leksono, B. dan T.Setyaji. 2004. Variasi Pertumbuhan Tinggi dan Diameter pada Uji Keturunan Eucalyptus pellita Sistem Populasi Tunggal. Jurnal Penelitian Hutan Tanaman. Vol. 1. No. 2. Pusat Penelitian dan Pengembangan Bioteknologi dan Pemuliaan Tanaman Hutan. Yogyakarta.

Leksono, B. 2010. Rencana Penelitian Integratif Pemuliaan Tanaman Hutan. Rencana Penelitian Integratif 2010 - 2014 Badan Penelitian dan Pengembangan Kehutanan Kementerian Kehutanan. Hal. 371 - 419. Badan Penelitian dan Pengembangan Kehutanan. Jakarta.

Mindawati, N. dan Y. Heryati. 2006. Pengaruh Frekuensi Pemeliharaan Tanaman Muda terhadap Pertumbuhan Meranti di Lapangan. Jurnal Penelitian Hutan Tanaman. Vol.3. No.2. Pusat Penelitian dan Pengembangan Peningkatan Produktivitas Hutan. Bogor. 
Mindawati, N., A.Irawan., I. Mansur. dan O.Rusdiana. 2010. Kajian Pertumbuhan Tegakan Hibrid Eucalyptus urograndis di Sumatera Utara. Jurnal Hutan Tanaman Vo. 7. No. 1. Pusat Penelitian dan Pengembangan Hutan Tanaman. Bogor.

Mindawati, N. 2011. Kajian Kualitas Tapak Hutan Tanaman Industri Hibrid Eucalyptus urograndis Sebagai Bahan Baku Industri dalam Pengelolaan Hutan Lestari (Studi Kasus di PT Toba Pulp Lestari, Simalungun, Sumatera Utara). Disertasi Pasca Sarjana. Institut Pertanian Bogor. Bogor.

PT ITCIKU. 2008. Pengembangan Nyawai (Ficus variegata). Perbenihan, Pembibitan, Penanaman dan Prospek Pengembangan. PT ITCIKU Balikpapan, Kalimantan Timur. Leaflet. (tidak diterbitkan).

Rachman, E. Hasil Analisa Tanah di KHDTK Cikampek. Balai Penelitian Teknologi Agroforestri Ciamis. tidak diterbitkan.

Riyanto, H.D. dan B.P.Pamungkas. 2010. Model Pertumbuhan Tegakan Hutan Tanaman Sengon untuk Pengelolaan Hutan. Tekno Hutan Tanaman. Vol.3. No.3. Pusat Penelitian dan Pengembangan Peningkatan Produktivitas Hutan. Bogor.
Siregar, S.T.H., Nurwahyudi. and Mulawarman. 2008. Effects of Inter-rotation Management on Site Productivity of Acacia mangium in Riau Province, Sumatera, Indonesia. In Nambiar (ed.) Site Management and Productivity in Tropical Plantation Forests. Proceedings of Workshops in Piracicaba (Brazil) 22-26 November 2004 and Bogor (Indonesia) 6-9 November 2006. Center for International Forestry Research (CIFOR). Bogor.

Suharlan, A., K.Sumarna dan J. Sudiono. 1993. Tabel Tegakan Sepuluh Jenis Kayu Industri. Informasi Teknis No. 39/1993. Pusat Penelitian dan Pengembangan Hutan. Bogor.

Sumarni, G., M.Muslich., N. Hadjib., Krisdianto., D. Malik., S.Suprapti., E.Basri., G.Pari., M.I. Iskandar dan R.M. Siagian. 2009. Sifat dan Kegunaan Kayu : 15 Jenis Andalan Setempat Jawa Barat. Pusat Penelitian dan Pengembangan Hasil Hutan. Bogor.

Vanclay, J.K.1994. Modelling Forest Growth and Yield. Application to Mixed Tropical Forest. CAB International. Guildfort. 